USAWC STRATEGY RESEARCH PROJECT

\title{
LIBERATION OR OCCUPATION? HOW FAILURE TO APPLY OCCUPATION LAW DURING OPERATION IRAQI FREEDOM THREATENED U.S. STRATEGIC INTERESTS
}

\author{
by \\ Colonel Lyle W. Cayce \\ United States Army \\ Colonel Thomas McShane \\ Project Advisor
}

This SRP is submitted in partial fulfillment of the requirements of the Master of Strategic Studies Degree. The views expressed in this student academic research paper are those of the author and do not reflect the official policy or position of the Department of the Army, Department of Defense, or the U.S. Government.

U.S. Army War College

CARLISLE BARRACKS, PENNSYLVANIA 17013 


\section{Report Documentation Page}

Form Approved

OMB No. 0704-0188

Public reporting burden for the collection of information is estimated to average 1 hour per response, including the time for reviewing instructions, searching existing data sources, gathering and maintaining the data needed, and completing and reviewing the collection of information. Send comments regarding this burden estimate or any other aspect of this collection of information,

including suggestions for reducing this burden, to Washington Headquarters Services, Directorate for Information Operations and Reports, 1215 Jefferson Davis Highway, Suite 1204, Arlington

VA 22202-4302. Respondents should be aware that notwithstanding any other provision of law, no person shall be subject to a penalty for failing to comply with a collection of information if it

does not display a currently valid OMB control number.

1. REPORT DATE

03 MAY 2004

4. TITLE AND SUBTITLE

Liberation or Occupation? How Failure to Apply Occupation Law

During Iraqi Freedom Threatened U.S. Strategic Interests

6. AUTHOR(S)

Lyle Cayce

7. PERFORMING ORGANIZATION NAME(S) AND ADDRESS(ES)

U.S. Army War College,Carlisle Barracks,Carlisle,PA,17013-5050

9. SPONSORING/MONITORING AGENCY NAME(S) AND ADDRESS(ES)

12. DISTRIBUTION/AVAILABILITY STATEMENT

Approved for public release; distribution unlimited

13. SUPPLEMENTARY NOTES

14. ABSTRACT

See attached file.

15. SUBJECT TERMS

16. SECURITY CLASSIFICATION OF:

a. REPORT unclassified b. ABSTRACT

unclassified c. THIS PAGE unclassified
3. DATES COVERED

5a. CONTRACT NUMBER

5b. GRANT NUMBER

5c. PROGRAM ELEMENT NUMBER

5d. PROJECT NUMBER

5e. TASK NUMBER

5f. WORK UNIT NUMBER

8. PERFORMING ORGANIZATION

REPORT NUMBER

10. SPONSOR/MONITOR'S ACRONYM(S)

11. SPONSOR/MONITOR'S REPORT NUMBER(S) 


\section{ABSTRACT}

AUTHOR: Colonel Lyle W. Cayce

TITLE: LIBERATION OR OCCUPATION? HOW FAILURE TO APPLY OCCUPATION LAW DURING OPERATION IRAQI FREEDOM THREATENED U.S. STRATEGIC INTERESTS

FORMAT: Strategy Research Project

DATE: 19 March 2004 PAGES: 39 CLASSIFICATION: Unclassified

Prior to and during Operation Iraqi Freedom, the U.S. Government asserted that coalition forces would be liberating rather than occupying forces to justify military intervention on humanitarian grounds, to reassure domestic and foreign audiences that the United States had no imperialistic ambitions in Iraq, and to avoid actions that might cause the Iraqi people to view invading forces as conquerors. As U.S. forces advanced into Iraq and other nations called upon the United States to act as an occupying power under international law, the United States refused and maintained that forces were liberating Iraq. When the United States displaced the Iraqi regime in Baghdad, U.S. forces did not immediately assume control of the city and restore order. The lawless period that followed cost U.S. forces the support of many Iraqis, complicated post-combat governance, and endangered the U.S. strategic goal of the creation of a democratic government. This paper argues that if the United States had planned and used occupation authority effectively, the United States could have prevented many of the problems that plague post-war Iraq. It recommends that the United States incorporate occupation law into future operations. 


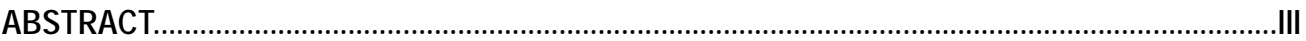

LIBERATION OR OCCUPATION? HOW FAILURE TO APPLY OCCUPATION LAW DURING OPERATION IRAQI FREEDOM THREATENED U.S. STRATEGIC INTERESTS ...................................

OCCUPYING POWERS UNDER THE GENEVA AND HAGUE CONVENTIONS ..................2

OBLIGATIONS AND RESPONSIBILITIES OF AN OCCUPYING POWER ............................

AUTHORITY GRANTED TO AN OCCUPYING POWER …...................................................

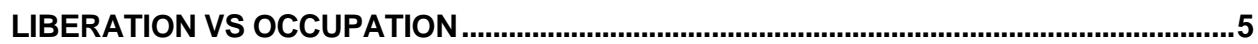

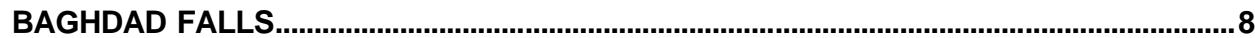

HOW AN AGGRESSIVE USE OF OCCUPATION LAW MIGHT HAVE CHANGED

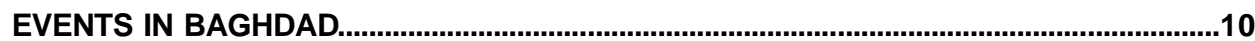

LESSONS TO BE LEARNED FROM THE FAILURE TO APPLY OCCUPATION LAW .....13

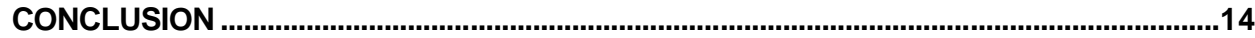

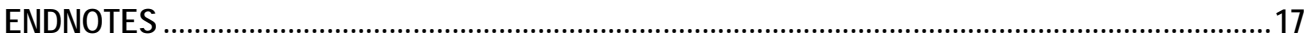

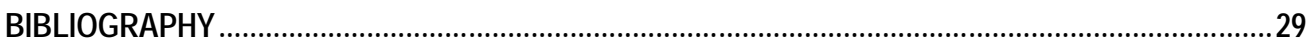




\section{LIBERATION OR OCCUPATION? HOW FAILURE TO APPLY OCCUPATION LAW DURING OPERATION IRAQI FREEDOM THREATENED U.S. STRATEGIC INTERESTS}

[T]here is nothing more difficult to carry out, or more doubtful of success, while nor more dangerous to handle, than to initiate a new order of things. For the reformer has enemies in all those who profit by the old order, and only lukewarm defenders in all those who would profit by the new order, this lukewarmness arising partly from fear of their adversaries, who have the laws in their favor; and partly from the incredulity of mankind, who do not truly believe anything new until they have had actual experience of it.

-Machiavelli

These words written over four hundred years ago to describe the challenges inherent in the administration of a newly acquired territory would have provided wise counsel as U.S. officials contemplated regime change and the creation of a democratic government in Iraq. Both allies and enemies objected to the bold proposal to reform Iraq. France and Russia (countries that profited from contracts under the Oil for Food Program), opposed military action against Iraq, as did other governments, members of Congress, International Humanitarian Groups, and anti-war activists.' Many opposed to intervention expressed concern that a United States led intervention would result in a long-term U.S. presence in Iraq. Some feared that invading Iraq would result in "another Vietnam"2 while others argued that the United States intended to establish a military occupation government in Iraq to control Iraqi oil. ${ }^{3}$

To respond to these concerns, the United States characterized the proposed military intervention as a humanitarian mission intended to liberate, not occupy, Iraq, and promised that U.S. forces would remain in Iraq only as long as necessary to destroy Weapons of Mass Destruction (WMD) and to create a new government. Over a nine-month period, the administration successfully convinced the majority of Americans that military intervention was necessary; obtained Congressional approval for the use of force in Iraq; and rallied a "Coalition of the Willing" to remove Saddam Hussein from power. ${ }^{4}$

The United States viewed the support of the Iraqi people as critical to success during combat and in post-war Iraq and avoided during the war actions that might cause the population to view U.S. forces as conquerors, rather than as liberating forces. Thus, as U.S. forces attacked and controlled significant portions of the country, the United States refused to concede that its "liberating" forces would become "occupying forces" as defined by international law.

This position effectively prevented military commanders from aggressively using the authority afforded to an occupying power under international law to control the occupied territory. Consequently, after Baghdad fell, widespread looting and violence damaged critical 
infrastructure and greatly complicated coalition efforts to create a democratic government in post-war Iraq. ${ }^{5}$

This paper considers whether an aggressive use of occupation authority by U.S. forces in Baghdad could have avoided the lawlessness that followed the regime's fall. The paper first reviews "occupation law" (primarily Articles 42-56 of the 1907 Hague Regulations and Articles 47-78 of the 1949 Fourth Geneva Convention) and outlines the obligations and rights afforded to occupying forces under international law. The paper then reviews how the United States characterized the use of force as a humanitarian mission to liberate the Iraqi people and explains how this position confused the international community and restricted U.S. commanders. After summarizing U.S. military actions in Baghdad prior to and following the regime's collapse, the paper considers several areas in which an immediate, aggressive use of occupation authority might have significantly altered events in Baghdad. The paper argues that, in the first crucial days after Baghdad fell, the U.S. lost momentum and initiative because it failed to take aggressive steps to ensure order. Finally, the paper concludes that strategic leaders must understand occupation law and that in future conflicts, the United States must use occupation law to accomplish strategic goals during all phases of military operations.

\section{OCCUPYING POWERS UNDER THE GENEVA AND HAGUE CONVENTIONS}

Many senior military and civilian leaders view international law in general (and the Geneva and Hague Conventions in particular), as constraints upon military operations. ${ }^{6}$ They interpret the provisions of international law as limiting military discretion and obliging the commander to divert assets and personnel to perform missions unrelated to military objectives. They consider particularly onerous the provisions of occupation law that require an occupying force to ensure order in the occupied territory and to meet the humanitarian needs of the local population.

In part, this view is valid; the conventions impose significant obligations upon military forces to regulate the vicious, unrestrained combat and destruction so often present in past conflicts. The provisions require commanders to protect entire classes of individuals, including wounded combatants, prisoners of war, displaced civilians, and inhabitants of an occupied territory. Yet with respect to occupation law, any view that concentrates solely upon the obligations imposed upon the occupier is incomplete, for the conventions grant the occupying force tremendous authority to control an occupied territory, recognizing the need for a strong presence to replace the overthrown government and ensure order. In reality, occupation law is a two-edged sword; it imposes obligations but also provides an effective administrator authority to control the occupied territory. 
According to the Geneva and Hague Conventions, occupation law applies when a military occupation exists. A military occupation is an "invasion plus taking firm possession of enemy territory for the purpose of holding it" and exists only when an invading force achieves effective control of a territory; that is, when an invading force has sufficient personnel to control and administer the territory invaded. ${ }^{8}$ A military occupation normally occurs when an invading force displaces the existing government, but not every invasion results in a military occupation. It is possible for an invading force to be an occupying force in one portion of an invaded country but not another due to the level of resistance and lack of control exercised. If an invading force pushes rapidly through a large portion of enemy territory without establishing effective control, no occupation occurs. Similarly, raiding parties and reconnaissance detachments, patrols, or even large combat forces quickly moving through an area do not occupy a territory. ${ }^{9}$ Whether an invasion results in a military occupation is a question of fact determined by the exact circumstances..$^{10}$ If the facts establish effective control, then invading forces become occupying forces and are then obligated to meet international law standards.

\section{OBLIGATIONS AND RESPONSIBILITIES OF AN OCCUPYING POWER}

Occupation law permits an invading force to control an area for the period of occupation. It does not transfer sovereignty to the occupant; it merely grants some of the rights of the displaced sovereign to the occupying power so that the occupying force can maintain order and administer the territory. ${ }^{11}$ Once a force achieves effective control and becomes an occupying power, occupation law imposes (among other requirements) upon the force the obligations to:

- Restore and maintain public order,; ${ }^{12}$

- Respect existing laws; $;^{13}$

- respect family honor, life, property, and religious practice, and permit spiritual assistance. $^{14}$

- Facilitate institutions devoted to the care and education of children; ${ }^{15}$

- Ensure the population receives food and medicine and bring in such material if necessary; ${ }^{16}$

- Facilitate relief schemes on behalf of the population; ${ }^{17}$ and

- Maintain hospitals, public health and hygiene services, and allow medical personnel to carry out their duties. ${ }^{18}$ 
In addition to the above obligations which require an occupying power to perform certain actions, occupation law also prohibits the occupying power from taking certain actions. For example, the occupying force may not:

- Deport protected persons, regardless of motive $;^{19}$

- Compel protected persons to serve in its armed or auxiliary forces, ${ }^{20}$

- Compel protected persons to work unless they are over eighteen years of age, ${ }^{21}$

- Abolish or suspend the rights of the nationals of the hostile party; ${ }^{22}$

- Coerce of take action against judges who abstain from fulfilling their functions for reasons of conscience; ${ }^{23}$ or

- Use mass punishments. ${ }^{24}$

The obligations and limitations listed above establish minimum requirements to ensure basic human rights for the inhabitants of an occupied territory. Yet they only tell part of the story, for the Geneva and Hague Conventions also provide the occupying power significant authority to control the day-to-day affairs of the people within the territory.

\section{AUTHORITY GRANTED TO AN OCCUPYING POWER}

The provisions of the Geneva and Hague Conventions pertaining to military occupations grant the occupying force and its personnel immunity from local law unless the occupant expressly provides otherwise. ${ }^{25}$ The provisions also permit the occupying force to:

- Demand and enforce obedience and to administer the territory. Do whatever is necessary (within limits) to maintain an orderly government and to ensure the security of the occupying power, its forces, and lines of communication; ${ }^{26}$

- Administer the territory through a military government or a mixed military/civilian administration; ${ }^{27}$

- Require officials and employees of public and private transportation systems and similar services to perform duties not involved in the war effort; ${ }^{28}$

- Require the occupied territory to bear reasonable costs related to the occupation, 29

- Modify (with some limitations) the local, provincial, or general government; ${ }^{30}$ 
- Repeal or suspend laws which threaten the occupying force (such as laws relating to recruitment and the bearing of arms) or any legislation inconsistent with the duties of the occupant (such as racial or gender based discriminatory laws) $;^{31}$

- Enact and enforce new criminal laws, after written notice to the local population, ${ }^{32}$

- Suspend courts if judges refuse to act or are corrupt and, set up courts when necessary to ensure that offenses against the local laws are tried:33

- Restrict movement, forbid travel, stop emigration and immigration, and require identification documents, ${ }^{34}$

- Regulate commerce, ${ }^{35}$

- Seize news facilities, censor the press, and prohibit or regulate newspapers; ${ }^{36}$

- Seize conveyances and regulate transportation, both public and private; ${ }^{37}$

- Use captured or seized enemy public property and private property validly captured on the battlefield and cash, funds, and realizable securities and all other property of the State and use them for operations of the war, ${ }^{38}$

- Seize ammunition of war $^{39}$

- Requisition labor for public works, ${ }^{40}$ and

- Require an oath from officials to perform conscientiously and not to act to the prejudice of the occupying power, and remove any official who declines; and require strict obedience from the official as long as he remains in office. ${ }^{41}$

These authorities provide the occupying power tremendous authority over the people in the occupied territory and, in effect, permit the occupying authority to control or exert influence over almost every aspect of life within the territory. Occupation law provides these authorities to an occupying force to enable the force to ensure order in the occupied territory, thereby minimizing risk of harm to civilian inhabitants and existing institutions.

\section{LIBERATION VS OCCUPATION}

Following the September 11, 2001 terrorist attacks against the United States, President Bush and other U.S. officials worried about a nightmare scenario in which terrorists obtained and used WMD against United States personnel or property. ${ }^{42}$ Officials concluded that Iraq, Iran, and North Korea presented the gravest threats to the United States, given their suspected involvement with terrorists, arms sales, and efforts to possess WMD. In his State of the Union Address on January 29, 2002, President Bush identified these countries as comprising an "Axis 
of Evil" and stated that the United States would not permit the world's most dangerous regimes to threaten the United States with these weapons. ${ }^{43}$

United States officials were convinced that a military intervention in Iraq was justified because Saddam Hussein was in material non-compliance with United Nations Security Council resolutions dating to the end of the 1991 Gulf War and because National Intelligence Estimates suggested that Iraq possessed WMD or was actively pursuing such weapons. Thus, during the summer of 2002, as Department of Defense personnel secretly planned for possible military action against Iraq, the President and senior administration officials tried to convince the American people, the Congress, and other nations of both the legitimacy and necessity of military action to enforce the United Nations Security Council resolutions against Iraq.

In making the case for intervention, the administration faced a dilemma. How could U.S. officials convince various audiences that force was justified, while reassuring them that the United States had no imperialistic motives or intent in Iraq? The brutality of the Iraqi regime presented the answer to this dilemma. Iraq's abysmal human rights record undermined the Iraqi government's moral legitimacy. Iraq counted few real friends in the community of nations and even Iraq's defenders conceded the cruelty of the Iraqi regime. The regime lacked internal popular support and many suggested that Iraqi military units would surrender en masse and that civilians would join invading armies to overthrow the regime.

Capitalizing upon this situation, the administration stressed the positive humanitarian consequences that would flow from military intervention. They argued that if force were necessary, invading forces would liberate the Iraqi people and rid the world of an evil regime. ${ }^{44}$ In making these arguments, the President and senior administration officials stressed regime's abuses and promised that U.S. forces would "leave as soon as possible" after a new government was created. ${ }^{45}$ Officials carefully avoided conceding that a military occupation would result, lest such an admission fuel claims of U.S. imperialism or undermine efforts to obtain support for military action. ${ }^{46}$ In effect, the United States used the positive humanitarian consequences that would follow regime change in Iraq to refute allegations of U.S. imperialistic goals in Iraq and to convince other countries to support military intervention.

Putting a humanitarian face on the proposed military intervention was a brilliant pubic affairs decision and the administration's focus upon Iraq's humanitarian record and Iraq's failure to comply with United Nations Security Council resolutions concerning treatment of the Iraqi people helped justify military action. ${ }^{47}$ In his September 12, 2002 address to the United Nations General Assembly demanding UN action against Iraq, President Bush justified action in part by arguing that Iraq had violated United Nations Resolutions concerning human rights. ${ }^{48}$ 
Subsequently, the United Nations Security Council cited the Iraqi regime's humanitarian record in Resolution 1441, which gave Iraq a final opportunity to meet disarmament obligations. ${ }^{49}$ Similarly, although Iraq's failure to comply with United Nations Security Council Resolutions regarding WMD was the primary justification for military action, the United States Congress expressly cited Iraqi humanitarian violations when it approved the use of force..$^{50}$

A second reason that U.S. officials insisted that invading forces would be liberating forces was because U.S. officials believed that Iraqi pubic support was crucial to efforts to efforts to establish a democratic government in post-war Iraq. ${ }^{51}$ The U.S. Government sought to avoid alienating the Iraqi population. It assumed that Iraqis would resent a conquering army but would welcome forces liberating them from an evil dictator. Therefore, on March 19, 2003, as President Bush announced in nearly simultaneous radio and television addresses to America and to Iraq that hostilities had begun, he reiterated the humanitarian justification for the war and informed the Iraqi people that the day of their liberation was near. ${ }^{52}$ Later, as U.S. and British forces attacked into Iraq, the United States insisted that invading forces were liberating forces ${ }^{53}$ while military commanders and spokespersons refused to concede that forces had become or would become occupying forces. ${ }^{54}$ To avoid the appearance of a military occupation or that the United States entered Iraq as conquerors, U.S. commanders ordered U.S. military units not to display the American flag during the invasion. Incredibly, the desire to avoid appearances of occupation were so great that LTG (Ret) Jay Garner, the head of the Office of Reconstruction and Humanitarian Assistance (ORHA), the occupation government, appeared to deny his mantle of authority when he said, "The new ruler of Iraq is going to be an Iraqi. I don't rule anything. ${ }^{155}$

Although a useful public affairs tool, the term liberating forces came with substantial baggage. The Geneva and Hague Conventions did not define the term and many questioned whether the U.S. sought to avoid the occupying power's obligation to meet the needs of the Iraqi people..$^{56}$ This was regrettable, for President Bush had promised to provide supplies and care for the Iraqi people and the United States intended to meet its occupation obligations. ${ }^{57}$ Yet confusion continued because U.S. officials promised to meet obligations but failed to state specifically that they would meet the occupying power obligations. On April 24, 2003, three weeks after the arrival of the first U.S. ground forces in Baghdad, United Nations SecretaryGeneral Kofi Annan personally called upon the Coalition to acknowledge that troops were occupying forces and to confirm their intent to meet obligations imposed by international agreements upon occupying powers. ${ }^{58}$ The U.S. response was swift. U.S. officials again stated that invading forces were liberating forces and promised that the United States would comply 
with applicable international standards, but failed to expressly state it would meet occupation obligations. ${ }^{59}$ Finally, on May 10, 2003 (nine days after President Bush declared the end of major combat operations ${ }^{60}$ and over one month after looting began in Baghdad) the U.S. Government acknowledged its status as an occupying power. ${ }^{61}$

\section{BAGHDAD FALLS}

On April 3, 2003, U.S. forces attacked and seized the southern half of the Baghdad International Airport. ${ }^{62}$ Between 4 April and 8 April, U.S. Army units engaged defending forces in a tremendous battle for Baghdad and secured key government buildings on the west side of the Tigris River. Beginning April 8, 2003, U. S. Marines fought their way into Baghdad on the east side of the Tigris River. As the Marines arrived in downtown Baghdad on April 9, 2003, most organized resistance ended.

The presence of U.S. military forces surprised the residents of Baghdad, as the regime had assured the population that U.S. forces were defeated outside the city. Residents took refuge in their homes and all organized activity ceased during the battle for Baghdad. On April 9,2003 , however, tens of thousands of Iraqis returned to the streets and celebrated their freedom. International television broadcast images of jubilant Iraqis trying unsuccessfully to pull down a large statute of Saddam Hussein. After obtaining the assistance of a United States Marine armored recovery vehicle, the citizens toppled the statue. The scene became a metaphor for Operation Iraqi Freedom; Iraqi citizens needed help to topple the statue just as they needed help to topple the dictator.

In the months preceding Operation Iraqi Freedom, many agencies and groups considered what might follow a regime change in Iraq. Studies warned that in the first crucial days following a regime change, the invading force rapidly had to establish order to create an environment conducive to completion of postwar goals. ${ }^{63}$ Commentators and experts predicted mass hysteria and warned that the military needed to be prepared to provide strong leadership and security until rational behavior returned. ${ }^{64}$ Regrettably, the predictions of hysteria and chaos proved true.

Throughout Baghdad, individual Iraqis settled grudges with former regime personnel or engaged in sporadic looting. Gradually, the looting increased until hundreds of thousands of people vented their frustration, anger, greed, and vengeance by looting, burning, and destroying government and private property throughout the city. At first, Iraqis attacked the statues of Saddam Hussein or buildings associated with the former regime. Soon, however, every facility and business was at risk. Over the next two weeks, Iraqis looted and damaged most 
government buildings and major infrastructure facilities in Baghdad, sparing only buildings guarded or occupied by U.S. forces or armed locals. As noted by two Brigade Commanders in Baghdad, "Robin Hood was alive and well" and looters engaged in a "massive redistribution of wealth. ${ }^{165}$

By April 11, 2003, many observers criticized the United States for failing to stop looting and violence in Baghdad and questioned the possible adverse consequences to U.S. strategic goals if the U.S. failed to restore order ${ }^{66}$ Most of these critics assumed that a strict liability standard applied, arguing that because U.S. forces had displaced the regime, the U.S. was automatically obliged to ensure order. ${ }^{67}$ In fact, as previously discussed, the obligation to ensure order applied only in areas for which the invading force had effective control. Although U.S. forces occupied key sections of the city and patrolled throughout the city, uniformed Iraqi, the paramilitary Saddam Fedayeen forces, and foreign actors from Syria and other nations attacked U.S. soldiers. ${ }^{68}$ While precise figures are unavailable, it is likely that between April 9, 2003 and April 20, 2003, fewer than 20,000 U.S. Soldiers and Marines were available to control Baghdad, a city of approximately five million people. It is questionable whether such a small force could effectively have controlled the hundreds of thousands of looters while continuing military operations. ${ }^{69}$

Based upon optimistic estimates, the United States anticipated that the Iraqi society and government would rapidly return to normal following the collapse of the Iraqi regime.

Accordingly, military officials tentatively planned for the early redeployment of the Third Infantry Division and instructed the division to limit planning solely to combat operations. ${ }^{70}$ They explained that follow-on units (primarily the United States Army Fourth Infantry Division and the First Armored Division) would perform the post-conflict stability mission in Baghdad. When Baghdad collapsed before these units arrived, the Third Infantry Division received orders to remain in Baghdad. The Third Infantry Division had received no guidance or specific training on reconstruction and policing missions, and little, if any, guidance from higher headquarters concerning the Iraq reconstruction plan. ${ }^{71}$ The Third Infantry Division staff immediately transitioned to crisis action planning for reconstruction and stabilization operations. ${ }^{72}$ The aggressive commanders who stormed Baghdad, precipitating the regime's early collapse, immediately sought to secure military objectives throughout the city, maintain the security of U.S. forces by locating and engaging remaining enemy combatants, and, with the Marines on the eastern side of the Tigris River, sought to police a city of five million inhabitants.

Department of Defense had directed military commanders to support ORHA, which would control and administer reconstruction and stabilization operations in post-war Iraq. Shortly after 
U.S. troops arrived in Baghdad, commanders received instructions "not to get too far out in front of ORHA"73 on occupation related issues. Yet commanders had little idea what ORHA intended, as they had no prior coordination with ORHA. ${ }^{74}$

Commanders knew that if they detained looters or used force to stop the lawlessness, they risked alienating the local population, complicating ORHA's post-war mission. Even in the face of widespread looting, they correctly rejected suggestions that U.S. troops use deadly force to deter looting as inconsistent with the claim that U.S. forces were liberating forces as well as contrary to U.S. practice and morality. ${ }^{75}$ Given all these considerations, commanders met humanitarian obligations to the Iraqi people but did not immediately fill the void created by the regime's collapse. ${ }^{76}$ As the U.S. moved more troops into the area and resistance diminished, troops stopped looting within their capability. By April 14, 2003, the United States operated joint patrols with Iraqi police in Baghdad and U.S. troops helped maintain order and detained

looters. ${ }^{77}$ As the Iraqi justice system was inoperative (like every other Iraqi institution), U.S. forces held most looters for only a few days and then released them with warnings. The United States detained longer those who committed serious offenses, in anticipation of trial by the reconstituted Iraqi Court system. ${ }^{78}$

By not taking control in Baghdad, the United States risked the loss of momentum and initiative and the gradual erosion of Iraqi goodwill towards U.S. forces. When U.S. forces displaced the Iraqi regime in Baghdad, they created a political and power vacuum. Nature abhors a vacuum and in the absence of U.S. action, locals took it upon themselves to establish order or seize power. One individual proclaimed himself Mayor of Baghdad. ${ }^{79}$ Shiite clergy established religious courts in the absence of government courts and organized checkpoints manned by ordinary Iraqis who searched cars for looted goods. ${ }^{80}$ Looting and lawlessness continued in Baghdad for several weeks. Gradually, however, a semblance of order returned to the city, although it is debatable whether this occurred due to looter fatigue, exhaustion of possible targets for looting, ${ }^{81}$ or U.S. efforts. Yet only after arrival of ORHA and the Coalition Provisional Authority (CPA) ${ }^{82}$ did the U.S. explicitly assert its authority under occupation law to control the city.

\section{HOW AN AGGRESSIVE USE OF OCCUPATION LAW MIGHT HAVE CHANGED EVENTS IN BAGHDAD}

Health care professionals know that treatment within the "golden hour" immediately following an injury increases dramatically the likelihood of survival and minimizes subsequent complications. The situation in Baghdad posed incredible challenges for military forces trying to maintain order and it is difficult to determine in retrospect what might have happened had the 
United States aggressively applied occupation authority. Nonetheless, one can postulate how occupation law might have minimized post-conflict lawlessness during Baghdad's "golden hour" (the time between the regime's fall and the outbreak of significant criminal activity.) ${ }^{83}$

First, the United States should have issued an immediate formal proclamation of occupation making clear that U.S. forces were in charge of the city and demanding order. ${ }^{84}$ While U.S. forces did not occupy all of Baghdad (in a legal sense) on April 9, 2003, because U.S. forces did not enjoy effective control of the entire city, this did not preclude the use of occupation authority throughout Baghdad, for a force can apply occupation rules even when it lacks effective control. ${ }^{85}$ A proclamation would contradict earlier claims that U.S. forces were liberating forces, yet U.S. officials needed only to point to international demands that the U.S. apply occupation law and explain that while the U.S. intent was to liberate Iraq, the United States was required temporarily to act as an occupying force to protect the Iraqi people. In effect, international law would have legitimized an aggressive use of occupation authority. ${ }^{86}$

As Baghdad spiraled into lawlessness, the situation required aggressive action. Many Iraqis were bewildered and confused by the disorder and lawlessness. A proclamation would let them know that someone was in charge - a matter of great importance. ${ }^{87} \mathrm{~A}$ proclamation would have reassured those Iraqis who preferred tyranny to disorder or who expected and preferred the United States to assert control. ${ }^{88}$

In April 2003, the Iraqi people had an exaggerated impression of U.S. capabilities. Despite the assurances from Iraqi media that Iraq was winning the war, Iraqis abruptly learned that the U.S. military had defeated the Iraqi forces and captured Baghdad in only three weeks. The United States seemed able to accomplish anything. Therefore, if something did not happen in Baghdad, it was because the United States did not want it to happen and Iraqis quickly blamed the United States. Iraqis believed rumors that U.S. troops permitted, encouraged, or engaged in looting, just as they later believed that the United States deliberately kept them without electrical power (a practice common under Saddam Hussein's regime.) The problems created by the destruction and lawlessness in Baghdad undermined the good will enjoyed initially by U.S. forces and turned many Iraqis against the United States. Ironically, although the United States eschewed an aggressive use of occupation authority by military forces to avoid alienating the Iraqi people, the failure to ensure order produced that very result.

Second, concurrent with the proclamation of occupation, the United States should have immediately explained to the Iraqi people the authority of the temporary military government, proposed a timetable for creation of an interim government, and provided additional instructions to ensure law and order. This order should have demanded Iraqi citizens obey proclamations of 
the occupying power and informed them that the authority would take quick action against those who failed to comply. Iraqis were accustomed to complying with edicts from an authoritarian government. Given the presence of armed U.S. troops in the city, it is likely that they would have accepted reasonable restraints intended and explained as necessary for the protection of the public. Presumably, a much smaller number would have failed to comply, presenting a more manageable challenge for U.S. forces.

Third, the United States immediately should have imposed a curfew within Baghdad to curtail lawlessness and protect property and residents. Authorities did not immediately impose a curfew because they recognized there were insufficient troops to enforce the order and there were no existing facilities to hold violators. While valid, these concerns were not necessarily conclusive and a curfew order backed by detention of violators would have helped establish order.

Fourth, the United States should have ordered Iraqi officials to return to duty in government positions and facilities unrelated to war activities. The order specifically should have directed that police, judges, court personnel, court security personnel, prison officials, prison guards, transportation and public service workers, utility workers, trash collectors, electrical workers, sanitation workers, and water department workers return to duty. This order would have contributed to a resumption of normal societal functions and the presence of personnel in government offices and facilities would have deterred looting or vandalism. ${ }^{89}$ As the order would have required Baath officials to return to duty, commanders could have removed these officials later, after proper vetting.

As part of the order to return to work, the United States should have paid immediately the salaries of individuals who returned to work. As most government workers had received no pay for over one month, this would attract large portions of the work force to return to critical organizations and encourage employees to comply. The money paid to these employees would help restart the local economy and encourage merchants to open businesses.

Shortly after arrival in Baghdad, the United States strongly encouraged workers to return to their positions. Initially, few Iraqi workers returned to duty. After the United States promised and made a one-time $\$ 20.00$ payment for government workers, however, a greater number returned to work. Had we ordered rather than encouraged workers to return and immediately paid salaries, many workers would have returned earlier, helping deter looting and restore order.

Fifth, U.S. forces immediately should have suspended Iraqi laws regarding the possession of firearms and outlawed the possession of weapons on the streets of Baghdad. Baghdad, like 
much of Iraq, was a fortified arsenal with hundreds of thousands of weapons and tremendous amounts of ammunition and explosive ordnance. Iraqis carried automatic weapons in public places and caused deaths and injuries due to intentional or accidental shootings. The presence of such weapons on the streets made force protection problematic for U.S. forces. An order outlawing the possession of such weapons in public would have enhanced public safety and made it easier for U.S. forces to identify remaining enemy combatants. ${ }^{90}$ While the CPA approved such an order on May 23, 2003, had the United States issued the order on 8 April, it might have significantly reduced the level of violence and crime. ${ }^{91}$

Sixth, the United States immediately should have used captured Iraqi funds to accomplish projects of a humanitarian or military nature to win the hearts and minds of the local population. The United States could have hired Iraqi workers to clean looted buildings; to provide security for sites the military could not protect; and to remove destroyed vehicles and debris blocking the roadways. Immediately after U.S. forces seized more than 700 million dollars in U.S. currency in Baghdad, Third Infantry Division officers proposed this course of action, but national level authorities rejected it due to an incorrect interpretation of U.S. fiscal law and inter-agency struggles regarding control of confiscated funds. The United States implemented this proposal later, but the impact was not as great as it might have been if implemented just as major resistance ended in Baghdad. ${ }^{92}$

This review suggests that application of occupation law might have changed conditions in post-war Baghdad. Yet it is unreasonable to fault commanders, for they were restrained by a U.S. policy designed to limit actions that might appear imperialistic. Clearly, however, had the United States planned for the possible use of occupation law during combat operations, U.S. forces would have been better prepared to restore order in Baghdad.

\section{LESSONS TO BE LEARNED FROM THE FAILURE TO APPLY OCCUPATION LAW}

Consideration of this issue suggests important lessons that strategic leaders should incorporate into future operational plans.

First, the United States must ensure that civilian and military leaders at all levels understand the authority and obligations of occupation law. This will ensure that occupation authority is considered by tactical and operational leaders. Additionally, it will eliminate misunderstandings such as the confusion regarding the use of captured enemy money. ${ }^{93}$

Second, the United States must ensure that occupation law is considered in all phases of operational war plans. The above discussion demonstrated that occupation law was relevant to 
decisions made during every phase of Operation Iraqi Freedom, yet the United States applied occupation law only as part of the post-conflict phase.

Third, the United States must ensure thorough coordination and exchange of information during the planning and execution process..$^{94}$ During Operation Iraqi Freedom, ORHA was not sufficiently involved in operational planning for combat operations and the military had insufficient information concerning ORHA's post-war plan. The military units actually controlling Baghdad received no guidance on key and essential tasks they would have to perform. The lack of coordination prevented commanders from shaping the post-conflict battlefield to help accomplish post-conflict goals. Had the occupation administration worked hand-in-glove with the combatant command, it is likely that many of the problems faced in post-war Baghdad would have been avoided.

Fourth, the United States must avoid strategic policies that restrict a commander's authority on the battlefield. Here, a legitimate desire to avoid alienating the Iraqi people led to the reluctance to take actions that might make U.S. forces appear to be conquering forces. This effectively denied commanders the authority to apply occupation law on the battlefield.

Finally, in future conflicts, the United States must plan for "worst-case" post-conflict scenarios. The otherwise brilliant coalition war plan assumed incorrectly that the United States would not need to assert occupation authority until ORHA or the CPA was operational in Iraq. In effect, this limited planning to a "best-case" scenario and failed to anticipate the lawlessness that followed the regime's fall. Had the United States planned for a worst-case scenario, forces would have arrived in Baghdad better prepared to establish order.

\section{CONCLUSION}

Machiavelli's advice regarding the difficulties in the creation of a "new order" proved as accurate in Iraq as it was in Italy four centuries earlier. It was not a threatened French veto in the Security Council or Republican Guard forces that posed the gravest threat to a new order in Iraq; rather, it was chaos and disorder endured to avoid the perception of imperialism. The United States preferred an occupation lite to heavy-handed decrees. Yet because the United States had limited troops in Baghdad and because ORHA was unable to perform the task, the United States should have announced a military occupation and attempted to restore order in Baghdad. In retrospect, the United States could have furthered its strategic interests had it heeded the decidedly Machiavellian advice offered by Stephen Rosen: "If one will be accused of being an imperialist regardless, one might as well be a competent imperialist." ${ }^{\prime 95}$ 
In future operations, strategic leaders and commanders must know and understand the obligations of an invading force under the Geneva and Hague conventions. Had the U.S. immediately used these authorities in Iraq in April 2003, the situation in Iraq today might be much different. Because this did not happen, we read reports in the morning newspapers and ask, "What might have been?"

WORD COUNT $=5856$ 


\section{ENDNOTES}

${ }^{1}$ The intensity of domestic opposition was surprising, since regime change had been the official U.S. policy since 1998. Iraq Liberation Act of 1998, Statutes at Large 112, sec. 3178 (1998).

${ }^{2}$ Robert Buzzanco, "America Can Still Avoid Another Vietnam in Iraq," 14 August 2002 , Available from <http://www.progressiveaustin.org/buzzanco.htm>; Internet; accessed 7 March 2004.

${ }^{3}$ David E. Sanger and Eric Schmitt "U.S. Has a Plan To Occupy Iraq, Officials Report" New York Times, 11 October 2002, Se. A, P. 1. (White House is developing detailed plan modeled on postwar occupation of Japan to install American-led military government in Iraq if United States topples Saddam Hussein; senior administration officials say plan also calls for war-crime trials of Iraqi leaders and transition to elected civilian government that could take months or years.) See also Jason Felch and Sandy Tolan "Beyond Regime Change," 1 December 2002; available at <http://www.globalpolicy.org/security/issues/ iraq/2002/1201beyond.html>; Internet; accessed 15 February 2004 (suggesting that real motivation to wage war against Iraq was to impose a "lengthy occupation" of Iraq in order to secure its vast oil resources for American and British oil companies.)

${ }^{4}$ Despite repeated references both before and after the war to "unilateral" action, the administration enjoyed significant support for intervention. The "Coalition of the Willing" counted at least forty-nine members, including: Afghanistan, Albania, Angola, Australia, Azerbaijan, Bulgaria, Colombia, Costa Rica, Czech Republic, Denmark, Dominican Republic, El Salvador, Eritrea, Estonia, Ethiopia, Georgia, Honduras, Hungary, Iceland, Italy, Japan, Kuwait, Latvia, Lithuania Macedonia Marshall Islands, Micronesia, Mongolia, Netherlands, Nicaragua, Palau, Panama, Philippines, Poland, Portugal, Romania, Rwanda, Singapore, Slovakia, Solomon Islands, South Korea, Spain, Tonga, Turkey, Uganda, Ukraine, United Kingdom, and Uzbekistan. White House Office of the Press Secretary, "Operation Iraqi Freedom" available from < http://www.whitehouse.gov/news/ releases/2003/03/20030327-10.html>; Internet; accessed 15 February 2004.

${ }^{5}$ In the months before operation Iraqi Freedom, many agencies and groups published studies that outlined post-conflict reconstruction efforts that might follow the fall of the Iraqi regime. Some of these experts predicted hysteria and warned that the military had to provide strong leadership and security until rational behavior returned. See Phyllis Mclntosh, "Protecting Iraqi Civilians: a Key Issue in Event of Military Action," Available from <http://www. useu.be/Categories/GlobalAffairs/Iraq/Feb1103ProtectionCivilians.html>; Internet; accessed February 10, 2004.

${ }^{6}$ Hague Convention No. IV, 18 October 1907, Respecting the Laws and Customs of War on Land, T.S. 539; Geneva Convention Relative to the Protection of Civilian Persons in Time of War, 12 August 1949, U.N.T.S. No. 973.

${ }^{7}$ Given U.S. Constitutional and statutory limitations upon U.S. military involvement in law enforcement activities, it is easy to understand why forces are reluctant to engage in such activities. Practical considerations (such as inadequate training) encourage restraint, even during military missions outside the United States. 
${ }^{8}$ An invading force occupies a territory when it has actual authority and control over the territory. An occupation extends only to the territory where authority has been established and can be exercised. Hague Convention art. 42; Geneva Convention, art 52. See also Department of the Army, Law of Land Warfare, Field Manual 27-10 (Washington, D.C.: 18 July 1956, Change 1, 15 July 1976,), 138. (Organized resistance must have been overcome and the force in possession must have taken measures to establish its authority.)

${ }^{9} \mathrm{FM} 27-10,138$.

${ }^{10}$ Hague Convention, art 42. Because occupation requires effective control, observers often disagree as to precisely when an occupation begins.

${ }^{11}$ The exercise of these rights results from the established power of the occupant and from the necessity of maintaining law and order, indispensable both to the inhabitants and to the occupying force. FM 27-10, 140.

${ }^{12}$ Since the authority of the former government has passed into the hands of the occupant, "the latter shall take all the measures in his power to restore, and ensure, as far as possible, public order and safety, while respecting, unless absolutely prevented, the laws in force in the country." Hague Convention, art. 43.

${ }^{13}$ Ibid.

${ }^{14}$ Hague Convention, art. 46.

${ }^{15}$ Geneva Convention, art. 50 .

${ }^{16}$ Geneva Convention, art. 55; FM 27-10, 146 (To the fullest extent of the means available to it, the Occupying Power has the duty of ensuring the food and medical supplies of the population; it should bring in the necessary foodstuffs, medical stores and other articles if the resources of the occupied territory are inadequate.)

${ }^{17}$ Geneva Convention, art. 59.

${ }^{18}$ Geneva Convention, art. 56.

${ }^{19}$ Geneva Convention, art 49.

${ }^{20}$ Hague Convention, art. 44; Geneva Convention, art. 51; FM 27-10, 154-56.

${ }^{21}$ Hague Convention, art. 23; Geneva Convention, art. 51; and FM 27-10, 410 (prohibition against forcing the inhabitants to take part in military operations against their own country precludes requisitioning their services upon works directly promoting the ends of the war, such as construction of fortifications, entrenchments, and military airfields or the transportation of supplies or ammunition in the zone of operations; but does not prohibit their being employed voluntarily.) See also Geneva Convention, art. 52, which precludes measures aiming at creating unemployment or restricting job opportunities in order to induce individuals to work for the Occupying Power 
${ }^{22}$ Hague Convention, art. 23; FM 27-10, 143 (It is especially forbidden to declare abolished, suspended, or inadmissible in a court of law the rights and actions of the nationals of the hostile party.)

${ }^{23}$ Geneva Convention, art. 54; FM 27-10, 156 (The Occupying Power may not alter the status of public officials or judges in the occupied territories or sanction them if they abstain from fulfilling their functions for reasons of conscience. The Occupying Power may remove public officials from their posts if they fail to perform their duties.)

${ }^{24}$ Hague Convention art. 50; Geneva Convention, art 33; FM 27-10, 164 (No general penalty, pecuniary or otherwise shall be inflicted upon the population on account of the acts of individuals for which they cannot be regarded as jointly and severally responsible.)

${ }^{25}$ FM 27-10, 143. Military and civilian personnel of the occupying forces and occupation administration and persons accompanying them are not subject to the local law or to the jurisdiction of the local courts of the occupied territory unless expressly made subject thereto by a competent officer of the occupying forces or occupation administration.

${ }^{26}$ Geneva Convention, art. 64; FM 27-10, 158 (It is the duty of the inhabitants to carry on their ordinary peaceful pursuits, to behave in an absolutely peaceful manner, to take no part in hostilities, to refrain from all injurious acts toward the troops or in respect to their operations, and to render strict obedience to the orders of the occupant.)

${ }^{27}$ FM 27-10, 141.

${ }^{28}$ Geneva Convention, art. 54. FM 27-10, 156 (The salaries of civil officials of the hostile government who remain in the occupied territory and continue the work of their offices, such as judges, administrative or police officers, officers of city or communal governments, are paid from the public revenues of the occupied territory.)

${ }^{29}$ Geneva Convention, art. 51; FM 27-10, 141.

${ }^{30} \mathrm{FM} 27-10,142$ (The occupant may, while retaining its paramount authority, permit the government of the country to perform some or all of its normal functions.)

${ }^{31}$ Hague Convention art. 23; Geneva Convention, arts. 51,64; FM 27-10, 142 (The occupant will continue the ordinary civil and criminal laws of the occupied territory except to the extent it may be authorized to alter, suspend, or repeal such laws. The occupant may alter, repeal, or suspend legislation constituting a threat to its security, such as laws relating to recruitment and the bearing of arms; legislation dealing with political process, such as laws regarding the rights of suffrage and of assembly; and legislation inconsistent with the duties of the occupant, such as laws establishing racial discrimination.)

${ }^{32}$ Geneva Convention, art. 64-65.

${ }^{33}$ Geneva Convention, art. 54.

${ }^{34}$ Geneva Convention, art. 48-49.

${ }^{35}$ FM 27-10, 144. 
${ }^{36}$ Hague Convention art. 53.

${ }^{37}$ FM 27-10, 144.

${ }^{38}$ U. S. Const., Art. I, sec. 8, cl. 11; FM 27-10, 150.

${ }^{39}$ Hague Convention art. 53.

${ }^{40}$ Geneva Convention, art. 51.

${ }^{41}$ FM 27-10, 156.

${ }^{42}$ White House Office of the Press Secretary, "Bush on Terrorism," 27 February 2002, available from <http://www.whitehouse.gov/news/releases/2002/02/20020227-6.html>; Internet; accessed 18 February 2004.

${ }^{43}$ George W. Bush, "State of the Union Address," 29 January 2002, available from <http://www.access.gpo.gov/ congress/sou/sou02.pdf>; Internet; accessed 15 February 2004.

${ }^{44}$ U.S. State Department, "Powell Says U.S. Will Liberate Iraq, Give Hope To Iraqis," 25 September 2003, available from <http://usinfo.state.gov/regional/nea/iraq/text2003/0331 pwl.htm>; accessed 5 March 2004. See also Donald H. Rumsfeld, "Testimony of United States Secretary of Defense Donald H. Rumsfeld to the Senate Armed Services Committee," 19 September 2002, available from <http://www.defenselink.mil/speeches/2002/s20020919secdef2.html>; Internet; accessed 5 March 2004.

${ }^{45}$ George W. Bush, "Radio Address by the President to the Nation," 7 December 2002 , available from <http://www.whitehouse.gov/news/releases/2002/12/20021207.html>; accessed 5 March 2004; George W. Bush, "Radio Address by the President to the Nation," 8 February 2003, available from <http://www.whitehouse.gov/news/releases/2003/02/20030208.html>; accessed on 5 March 2004. See also Paul Wolfowitz, "Remarks as Prepared for Delivery by Deputy Secretary of Defense," 23 February 2003, available from < http://www.pentagon.gov/ speeches/2003/ sp20030223-depsecdef0042.html>; accessed February 15, 2004. Quoting Secretary Rumsfeld, Mr. Wolfowitz noted that the United States would be guided by two commitments in Iraq: "Stay as long as necessary, and leave as soon as possible."

${ }^{46}$ Robert Jensen, "Powell Dodges The 'O' Word In UN Address," Albion Monitor, 6 February 2003; available from <http://www.monitor.net/monitor/0302a/powellraqun1.html>; Internet; accessed 9 March 2004. The Economist, "Iraq's oil -- Don't mention the O-word," 12 September 2002; available from <http://www.economist.com/displaystory.cfm?story_id= 1325264Internet>; accessed 12 March 2004.

${ }^{47}$ While the administration adopted this strategy to gain domestic and international support, it appears that officials genuinely believed that that invading troops would be "liberating" an oppressed people. Interestingly, the American soldiers who fought the war also viewed themselves as liberating forces. See Leonard Wong et al., Why They Fight: Combat Motivation in the Iraq War, U.S. Army War College, Strategic Studies Institute, July 2003); also available from < http://carlisle-www.army.mil/ssi/pubs/2003/ whyfight/whyfight.pdf>; accessed 5 March 2004. 
${ }^{48}$ During his address to the United Nations, President Bush cited the 2001 report of the U.N. Commission on Human Rights, which found that Iraq continued to commit grave violations of human. He quoted the Commission's finding of tens of thousands of political opponents and ordinary citizens subjected to arbitrary arrest and imprisonment, summary execution, and torture by beating and burning, electric shock, starvation, mutilation, and rape. George W. Bush, "Address to the United Nations," 12 September 2002, available from <http://www.whitehouse.gov/news/releases/ 2003/09/20030923-4.html>; Internet; accessed 5 March 2004.

${ }^{49}$ United Nations Security Council, Resolution 1441. S/RES/1141(2003). New York: United Nations, 8 November 2002. Database on-line. (Established an enhanced inspection regime for Iraq's disarmament to be carried out by the U.N. Monitoring, Verification, and Inspection Commission (UNMOVIC) and the International Atomic Energy Agency and gave Iraq a final opportunity to comply with disarmament obligations.)

${ }^{50}$ Authorization For Use of Military Force Against Iraq Resolution of 2002, Statutes at Large 116, sec. 1498 (2002).

${ }^{51}$ U.S. efforts in Germany and Japan following World War II proved that it was possible to establish stable democracies from the remnants of totalitarian societies -- but that such a process was neither inexpensive nor quick. See Conrad Crane and Andrew Terrill, Reconstructing Iraq: Insights, Challenges, and Missions for Military Forces in a Conflict Scenario, U.S. Army War College, Strategic Studies Institute, February 2003.

${ }^{52}$ George W. Bush, "Address to the Nation" 19 March 2003; available from www. White house.gove/news/releases/2003/03/iraq/20020219-17.html; Internet, accessed 1 October 2003.

My fellow citizens: At this hour, American and coalition forces are in the early stages of military operations to disarm Iraq, to free its people and to defend the world from grave danger. . . . We come to Iraq with respect for its citizens, for their great civilization and for the religious faith they practice. We have no ambition in Iraq except to remove a threat and restore control of that country to its own people. Many Iraqis can hear me tonight in a translated radio broadcast, and I have a message for them. If we must begin a military campaign, it will be directed against the lawless men who rule your country and not against you. As our coalition takes away their power, we will deliver the food and medicine you need. We will tear down the apparatus of terror and we will help you to build a new Iraq that is prosperous and free. In a free Iraq, there will be no more wars of aggression against your neighbors, no more poison factories, no more executions of dissidents, no more torture chambers and rape rooms. The tyrant will soon be gone. The day of your liberation is near.

After Saddam Hussein failed to comply with Resolution 1441, France and Russia thwarted United States efforts to obtain a supplemental United Nations Security Council expressly authorizing the use of force against Iraq. Subsequently, on March 17, 2003, President Bush issued an ultimatum for Saddam and his sons to leave Iraq. When Saddam Hussein failed to comply, the Coalition began offensive operations. Congressional Research Service, Iraq War: Background and Issues Overview, 15 April 2003 (Washington, D.C.: Library of Congress, 2003. 
${ }^{53}$ White House Office of the Press Secretary, "Global Message," 2 April 2003, available from <http://www.whitehouse.gov/ news/releases/ 2003/04/20030402-4.html>; accessed 16 February 2004; "We give this pledge to the citizens of Iraq: We're coming with a mighty force to end the reign of your oppressors. We are coming to bring you food and medicine and a better life, and we will not relent until your country is free."

${ }^{54}$ BG Vincent Brooks, "US Central Command Daily Briefing," 14 April 2003, available from <http://www.usinfo.state.gov/topical/pol/terror/texts/03041407.htm>; accessed 11 January 2004:

"[l]t's still a bit premature for me to declare what our status is.... what we do know is that we have responsibilities as a force that has entered. The specific references to occupying power are very precise and very legalistic, and I'm not really in the best position to be able to give you information on that. We'll give you some more as time goes on as it relates to that specific concern....Right now we're still a liberating force, and that's how we're approaching our operations....Whether that changes over time needs to be seen.

BG Brooks' comments reflect the difficulty in determining when a force has effective control of territory. During asymmetric combat as occurred in Iraq, with units moving long distances, bypassing enemy formations and cities, it was difficult to determine when the force achieved effective control of an area and met the legal definition of an occupying force.

${ }^{55}$ Kathleen Rhem, "Iraqis Need Work, Paychecks, U.S. Administrator Says," 24 April 2003, available from <http://www.dod.mil/news/Apr2003/n04242003_200304242.html>; accessed 29 Jan 04.

${ }^{56}$ U.S. officials consistently denied that U.S. forces were or would become occupying forces, even as the United States created an occupation government. The U.S. position fueled arguments that that the United States complied with international standards only when it was convenient.

${ }^{57}$ White House Office of the Press Secretary, "Remarks by the President Upon Return From Camp David," 23 March 2003; available from <http://www.whitehouse.gov/news/ releases/2003/03/20030323-1.html>; accessed 12 February 2004.

${ }^{58}$ Kofi Annan, "UN Secretary-General to Commission on Human Rights: We must Hope a New Era of Human Rights in Iraq will Begin Now," 24 April 2003; available from <http://www. unhchr.ch/huricane/huricane.nsf/0/975E2E36F2593DCAC1256D12002DDDBF?opendocument >; Internet; accessed 10 October 2003.

What we must all hope is that a new era of human rights in Iraq will now begin, with the end of the war. And here, in the first instance, I hope the Coalition will set an example by making clear that they intend to act strictly within the rules set down by the Geneva Conventions and the Hague Regulations regarding the treatment of prisoners of war, and by demonstrating through their actions that they accept the responsibilities of the Occupying Power for public order and safety, and the well-being of the civilian population. 
${ }^{59}$ Department of State Office of the Press Secretary, "U.S. Diplomats Object to Annan Statements on Iraq," 24 April 2003, available from <http://usinfo.state.gov/topical/ pol/usandun/03042402.htm>; Internet; accessed 18 January 2004.

We find it - at best - odd that the Secretary General chose to bring this to our attention. The US has said that it has not yet established whether it is the occupying power under international law, but is nevertheless respecting the rules....We are simply saying that the issue of an occupying power has not yet been dealt with. Once again the situation is still quite fluid. We will come to that, and presumably come to it quickly. But there should be no question -- certainly no question in the mind of the Secretary General -- that we need to make any clearer than we already have, and have been on the record repeatedly as being in conformance and wanting to be in conformance in every way with the Geneva Conventions.

${ }^{60}$ White House Office of the Press Secretary, "President Bush Announces Major Combat Operations in Iraq Have Ended, Remarks by the President from the USS Abraham Lincoln At Sea Off the Coast of San Diego, California," 1 May 2003, available from<http://www. whitehouse.gov/news/releases/ 2003/05/iraq/20030501-15.html>; Internet; accessed 15 February 2004.

${ }^{61}$ In a joint letter to the United Nations Security Council, the United States and Great Britain confirmed the existence of an occupation government, promised to protect and hold Iraqi assets for the good the Iraqi people, and promised to meet obligations as occupying powers. The letter also proposed the end of the thirteen-year long sanction program. Jeremy Greenstock and John D. Negroponte, "Letter from the Permanent Representatives of the UK and the US to the UN, addressed to the President of the Security Council," 8 May 2003, available from <http://www. globalpolicy.org/security/issues/iraq/document/2003/0608usukletter.htm>; Internet; accessed 5 March 2004. The United Nations later recognized the nations as occupying powers. United Nations Security Council, Resolution 1483. S/RES/1483(2003). New York: United Nations, 22 May 2003 (Recognizing the United States and the United Kingdom as occupying powers with specific authorities, responsibilities, and obligations under applicable international law.)

${ }^{62}$ U.S. military commanders immediately changed the name of the facility from the "Saddam Hussein Airport" to "Baghdad International Airport (BIAP)."

${ }^{63}$ See, for example Crane (Noting importance of quickly restoring order.); Center for Strategic and International Studies and the Association of the United States Army, Post-Conflict Reconstruction Task Framework, May 2002; available from <http://www.csis.org/isp/pcr/ framework.pdf>; Internet; accessed 12 March 2003 (Noting that the four "pillars" of post-conflict reconstruction included security, justice and reconciliation, social and economic well-being; and governance and participation, and that creation of security was precondition for achieving all other outcomes): Center for Strategic and International Studies. A Wiser Peace: An Action Strategy for a Post-Conflict Iraq, Washington: Center for Strategic and International Studies, January 2003. Also available from <http://www.csis.org/isp/wiserpeace.pdf >; Internet; accessed 18 August 2003.

${ }^{64}$ The United States should have appreciated the possibility of disorder and lawlessness following the overthrow of the Iraqi regime, given experiences in Panama and Haiti and the 
warnings received. Council on Foreign Relations, and Rice University's James A. Baker III Institute for Public Policy. Guiding Principles for U.S. Post-Conflict Policy in Iraq: Report of an Independent Working Group.. December 2002. Available from <http://www.cfr.org/pdf/PostWar_Iraq.pdf>; Internet. Accessed 20 August 2003 (recommending U.S. be prepared to pivot quickly from combat operations to stability operations to prevent Iraq from descending into chaos.) Numerous other reports and studies reached similar conclusions, although the Democratic Principles Working Group (part of the United States State Department "Future of Iraq" project) expressly stated that "Nothing in this report, however, requires of the United Nations or United States to police or manage into existence the new and budding democratic institutions. That is a challenge that the people of Iraq must and will face up to on their own." Democratic Principles Work Group. Final Report on the Transition to Democracy in Iraq. November 2002. p.5. Available from <http://www.iraq foundation.org/studies/2002/dec/ study. pdf >; Internet; accessed 5 August 2003.

${ }^{65}$ During the Third Infantry Division Battle Update Briefing on 12 April 2003, COL Dan Allyn, the Third Brigade Combat Team Commander, described the widespread looting occurring in his brigade's sector as a "massive redistribution of wealth." In describing looting activity in his sector, COL David Perkins, the Third Infantry Division Second Brigade Combat Team Commander stated, "Robin Hood is alive and well." Author's personal notes. It would have been more correct had COL Perkins referenced Ali Baba, the famous Baghdad street urchin. Author's personal notes.

${ }^{66}$ Margaret Warner, "Days of Disorder" 11 April 2003; Available from <http://www.pbs.org/ newshour/bb/military/jan-june03/disorder_4-11.html>; Internet, accessed 5 October 2003.

${ }^{67}$ See, for example, Michael Schmitt, "The Law of Belligerent Occupation," 15 April 2003, Available from <http://www.crimesofwar.org/special//raq/news-iraq5.html>; Internet, accessed 12 October 2003 (noting that Human Rights Watch charged that some U.S. government officials seemed unaware of their obligations under international law to act promptly to prevent looting and other disturbances.)

${ }^{68}$ LTC Peter Bayer, formerly the Operations Officer (G-3) for the United States Army Third Infantry Division, interview by author, 8 March 2004.

69 Some have suggested that an Army must invade with sufficient troops to ensure law and order in the occupied territory following the invasion. Occupation law imposes no such obligation.

${ }^{70}$ Bayer Interview.

${ }^{71}$ Ibid.

${ }^{72}$ Ibid.

${ }^{73}$ Ibid; Author's personal notes.

${ }^{74}$ The Third Infantry Division's first coordination with ORHA followed the arrival in Baghdad of the ORHA advance team on approximately April 16, 2003. On April 17, 2003, the author visited the advance team to determine how best to support ORHA. The advance team 
conceded that there was no written plan but offered to let the author look at a PowerPoint slide show presentation that they used as a draft plan. Author's personal notes.

${ }^{75}$ Hamza Hendawi, "U.S. Military Says It Is Aggressively Targeting Looters But Denies Shoot-To-Kill Order," 14 May 2003, available from <http://www.sfgate.com/cgi-bin/article.cgi?f=/ news/a/2003/05/14/international1106EDT0564.DTL HAMZA HENDAWI>; Internet; accessed 12 March 2004; Bayer Interview; LTC Rick Gibbs, formerly the Operations Officer (G-3) for the United States Army $101^{\text {st }}$ Air Assault Division, interview by author, 8 March 2004.

${ }^{76}$ Soldiers ensured that food and medicine were available to the local population and located, inventoried, and made equitable distribution to clinics of drugs and medicines purchased under the United Nations Oil for Food Program that U.S. forces found stockpiled in Iraqi warehouses. Saddam's regime had withheld these drugs from clinics and hospitals, creating artificial shortages. These fully stocked warehouses refuted the arguments of many who previously had argued that the United Nations sanctions program had caused the deaths of hundreds of thousands of Iraqi children. Author's personal notes; Bayer Interview. Additional supplies arrived 11-12 April 2003, when Kuwaiti Air Force C-130s delivered 24 tons of medical supplies for hospitals and health clinics in Baghdad. The U.S. Army delivered these supplies after a needs-assessment. White House Office of the Press Secretary, "Operation Iraqi Freedom, Humanitarian Update," 16 April 2003, Available from <http://www.whitehouse.gov/ news/ releases/2003/04/20030416-1.html>; accessed 6 March 2004.

${ }^{77}$ Center for Defense Information, "Eye on Iraq, War Update," April 22, 2003, available at <http://www.cdi.org/>; accessed 10 March 2004.

${ }^{78}$ Hendawi.

${ }^{79}$ American Forces Press Service, "Coalition Forces Detain Self-Proclaimed Mayor of Baghdad," 28 April 2003, available from < http://www.defenselink.mil/news/Apr2003/ n04272003_200304272.html>; Internet; accessed 6 March 2004.

${ }^{80}$ Center for Defense Information, "Eye on Iraq, War Update."

81 Ibid.

${ }^{82}$ The President named Ambassador L. Paul Bremer as Envoy to Iraq. White House Office of the Press Secretary, "President Names Envoy to Iraq," May 6, 2003, available at <http://www.whitehouse.gov/news/releases/2003/05/20030506-5.html>; Internet; accessed 12 March 2004. On May 16, 2003, Ambassador Bremer promulgated a regulation that established the Coalition Provisional Authority as the occupation administration, under the authority of the laws and usages of war and United Nations Security Council Resolution 1483. Coalition Provisional Authority, Regulation 1, Coalition Provisional Authority Regulation No. 1, 16 May 2003, available from <http:// www.cpa-iraq.org/regulations/REG1.pdf>; Internet; accessed 6 March 2004. CPA later assumed the functions of ORHA.

${ }^{83}$ Tactical commanders recommended that these be implemented, but the request was rejected or delayed for various reasons. Author's personal notes. The CPA later implemented most of the proposals. This paper argues that the positive results produced by the measures were not as great as might have been realized had they been available earlier. 
${ }^{84}$ A proclamation of military occupation was not required under international law. Hague Convention art. 42.

${ }^{85}$ FM 27-10, 138.

${ }^{86}$ A proclamation of occupation would silence critics who contended that the United States was avoiding its obligations as an occupying power and not doing enough to ensure order in Iraq. A proclamation and aggressive efforts to restore order in Baghdad might also have aided U.S. efforts to obtain international financial support for Iraqi reconstruction. Ironically, the U.S. would have been largely immune from later criticism if it took aggressive action, exactly the reverse of the situation at the start of the war. The down side to such an action would be small; even if the use of occupation law failed to help keep order.

${ }^{87}$ Over one month after U.S. forces entered Baghdad, people still wondered who ruled Baghdad. See Noah Feldman, "Truth, War and Consequences: What's at Stake?: Islamic Democracy in a new Iraq," available from <http://www.pbs.org/wgbh/pages/frontline/ shows/truth/ stake/feldman.html>; accessed 12 February 2004. Mr. Feldman related a conversation he had in Baghdad:

An Iraqi literally said to me -- in May, when I got there -- an ordinary guy on the street in a Shia neighborhood, said to me, "Who is the government. . . . And I said to him, "What do you mean 'Who' is the government?" He said, "You know, who is the government?" After 30 years of dictatorship, I suppose that's how you phrase it. . . . So, I finally said to him, "Oh, Ambassador Bremer is the government." He said, "Oh, okay, as long as someone is in charge.

${ }^{88}$ Few Americans understood how Iraqis could lament Saddam's departure only weeks after they obtained their freedom. However, as the Iraqis faced the disorder and inconveniences of post war Baghdad, they may well have remembered the ancient Arab proverb: "Better 60 years of tyranny than one day of anarchy." Thomas Friedman, From Beirut to Jerusalem, (New York, 1989).

${ }^{89}$ If electrical utility workers had returned to the electrical substations or power generation facilities, it is unlikely that they would have restored power. Yet their very presence at the city's electrical substations and other facilities would have provided additional security for the facilities.

${ }^{90}$ Ideally, it would have been better to outlaw all fully automatic weapons. Unfortunately, the United States would have lost support of a majority of the Iraqi population had it outlawed AK 47's for most Iraqi households had such weapons and removing them would have left Iraqis defenseless against armed criminals. An adequate compromise was to make public possession of such weapons illegal. If this had been done on April 8, 2003, it would have contributed to a quicker return of law and order.

91 Coalition Provisional Authority, Coalition Provisional Authority Order Number 3 , Weapons Control (CPA/ORD 23 May 2003/03); <http://www.cpa-iraq.org/regulations/ 20040818a_CPAORD3.pdf>; Internet; accessed 15 February 2004.

${ }^{92}$ International law recognizes that a force may seize and use the property of the opposing state. Within a few weeks, the issue was resolved and higher commands authorized use of the 
funds for occupation related expenses. At first, cumbersome disbursement and accounting rules diminished the program's effectiveness. After the rules were relaxed, however, the program enjoyed great results. Still, the funds had less impact than if they had been available to commanders immediately. Author's personal notes. For a discussion of how the funds were used by tactical commanders, see LTC Mark Martins, "The CERP in Iraq," (Draft article for publication in the February 2004 Army Lawyer).

${ }^{93}$ This confusion over whether captured enemy funds could be used for occupation related expenses highlights a fundamental lack of understanding of international law.

${ }^{94}$ James Reed, "Should Deterrence Fail: War Termination in Campaign Planning, From Parameters, Summer 1993, pp. 41-52. Available from <http://carlisle-www.army.mil/usawc/ Parameters/1993/reed.htm>; Internet, accessed 12 March 2004. (End of hostilities and transition to a new post-conflict phase characterized requires effective planning and coordination before the fact.)

${ }^{95}$ Stephen Rosen, Wall Street Journal, 4 April 2003, pg. A.8. 


\section{BIBLIOGRAPHY}

American Forces Press Service. "Coalition Forces Detain Self-Proclaimed Mayor of Baghdad." 28 April 2003. Available from < http://www.defenselink.mil/news/Apr2003/ n04272003_200304272.html>. Internet. Accessed 6 March 2004.

Annan, Kofi. "UN Secretary-General to Commission on Human Rights: We must Hope a New Era of Human Rights in Iraq will Begin Now." 24 April 2003. Available from <http://www. unhchr.ch/huricane/huricane.nsf/0/975E2E36F2593DCAC1256D12002DDDBF?opendocu ment>. Internet. Accessed 10 March 2004.

Authorization For Use of Military Force Against Iraq Resolution of 2002, Statutes at Large 116, sec. 1498 (2002).

Bush George W. Bush. "Address to the United Nations." 12 September 2002. Available from <http://www.whitehouse.gov/news/releases/2003/09/20030923-4.html>. Internet. Accessed 5 March 2004.

. "Address to the Nation." 19 March 2003. Available from <www.whitehouse.gove/news/ releases/2003/03/iraq/20020219-17.html . Internet. Accessed 1 October 2003.

"Radio Address by the President to the Nation." 7 December 2002. Available from <http://www.whitehouse.gov/news/releases/2002/12/20021207.html>. Internet. Accessed 5 March 2004.

"Radio Address by the President to the Nation." 8 February 2003. Available from <http://www.whitehouse.gov/news/releases/2003/02/20030208.html>. Internet. Accessed 5 March 2004.

State of the Union Address. 29 January 2002. Available from <http://www.access. gpo.gov/ congress/sou/sou02.pdf>. Internet. Accessed February 15, 2004.

Buzzanco, Robert. "America Can Still Avoid Another Vietnam in Iraq." 14 August 2002. Available from <http://www. progressiveaustin.org/buzzanco.htm>. Internet. Accessed 7 March 2004.

Center for Defense Information. "Eye on Iraq, War Update." 22 April 2003. Available from <http://www.cdi.org/>. Accessed 10 March 2004.

Center for Strategic and International Studies and the Association of the United States Army. Post-Conflict Reconstruction Task Framework. May 2002. Available from <http://www .csis.org/isp/pcr/framework.pdf>. Internet. Accessed 12 March 2003.

Center for Strategic and International Studies. A Wiser Peace: An Action Strategy for a PostConflict Iraq. Washington, D.C.: Center for Strategic and International Studies. January 2003. Also available from <http://www.csis.org/isp/wiserpeace.pdf>. Internet. Accessed 18 August 2003. 
Center for Strategic and International Studies. Post-War Iraq: Are We Ready? Washington, D.C.: Center for Strategic and International Studies, 3 June 2003. Available from <http://www.csis.org/isp/ areweready2.pdf>. Internet. Accessed 12 March 2004.

Coalition Provisional Authority. Coalition Provisional Authority, Regulation 1. 16 May 2003. Available from <http:// www.cpa-iraq.org/regulations/REG1.pdf>. Internet. Accessed 6 March 2004.

Coalition Provisional Authority. Coalition Provisional Authority Order Number 3, Weapons Control. 23 May 2003. Available from <http://www.cpa-iraq.org/regulations/ 20040818a_CPAORD3.pdf>. Internet. Accessed 15 February 2004.

Congressional Research Service, Iraq War: Background and Issues Overview. (Washington, D.C.: Library of Congress, 15 April 2003.)

Conrad Crane and Andrew Terrill. Reconstructing Iraq: Insights, Challenges, and Missions for Military Forces in a Conflict Scenario. U.S. Army War College, Strategic Studies Institute, February 2003

Crane, Conrad C. Civil, Military, and Political Cooperation in Conflict Resolution and PostConflict Rebuilding. Conference brief. Carlisle Barracks: U.S. Army War College, Strategic Studies Institute, 2002. Also available from <http://www.carlisle.army.mil/ ssi/conf/2002/rebuild.htm>. Internet. Accessed 12 March 2004.

Council on Foreign Relations and Rice University's James A. Baker III Institute for Public Policy. Guiding Principles for U.S. Post-Conflict Policy in Iraq: Report of an Independent Working Group. December 2002. Available from <http://www.cfr.org/pdf/Post-War_Iraq.pdf>. Internet. Accessed 20 August 2003.

Democratic Principles Work Group. Final Report on the Transition to Democracy in Iraq. November 2002. Available from <http://www.iraqfoundation.org/studies/2002/dec/ study.pdf>. Internet. Accessed 5 August 2003.

Department of State, Office of the Press Secretary. "U.S. Diplomats Object to Annan Statements on Iraq." 24 April 2003. Available from <http://usinfo.state.gov/topical/ pol/usandun/03042402.htm>. Internet. Accessed 18 January 2004.

Department of the Army, Law of Land Warfare, Field Manual 27-10. Washington, D.C.: U.S. Department of the Army, 18 July 1956, Change 1, 15 July 1976.

Djerejian, Edward P. and Wisner, Frank G. Guiding Principles for U.S. Post-Conflict Policy in Iraq: Report of an Independent Working Group. December 2002. Available from <http://www.cfr.org/pdf/Post-War_Iraq.pdf>. Internet. Accessed 12 March 2004.

Dobbins, James. "Nation-Building: The Inescapable Responsibility of the World's Only Superpower." Rand Review27 (Summer 2003): 16-27.

Fallows, James. "Blind into Baghdad." The Atlantic Monthly (January/February 2004). 
Felch, Jason and Tolan, Sandy. "Beyond Regime Change." 1 December 2002. Available from <http://www.globalpolicy.org/security/issues/ iraq/2002/1201beyond.html>. Internet. Accessed 15 February 2004.

Feldman, Noah. "Truth, War and Consequences: What's at Stake?: Islamic Democracy in a new Iraq." Available from <http://www.pbs.org/wgbh/pages/frontline/shows/truth/ stake/feldman.html>. Internet. Accessed 12 February 2004.

Friedman, Thomas. From Beirut to Jerusalem. (New York, 1989.

Geneva Convention for the Amelioration of the Condition of Wounded, Sick, and Shipwrecked Members, 12 August 1949, 75 U.N.T.S. 85

Geneva Convention Relative to the Protection of Civilian Persons in Time of War. 12 August 1949, U.N.T.S. 973.

Geneva Convention, Relative to the Treatment of Prisoners of War, 12 August 1949, 75 U.N.T.S. 135.

Greenstock, Jeremy and Negroponte, John D. Letter from the Permanent Representatives of the UK and the US to the UN, addressed to the President of the Security Council. 8 May 2003. Available from <http://www. globalpolicy.org/security/issues/iraq/document/ 2003/0608usukletter.htm>. Internet. Accessed 5 March 2004.

Hague Convention No. IV, 18 October 1907, Respecting the Laws and Customs of War on Land, 75 U.N.T.S. 539.

Hendawi, Hamza. "U.S. Military Says It Is Aggressively Targeting Looters But Denies Shoot-ToKill Order." 14 May 2003. Available from <http://www.sfgate.com/cgi-bin/article.cgi?f=/ news/a/2003/05/14/international1106EDT0564.DTL HAMZA HENDAWI>. Internet. Accessed 12 March 2004.

Iraq Liberation Act of 1998. Statutes at Large 112, sec. 3178 (1998).

Jensen, Robert. "Powell Dodges The 'O' Word In UN Address." Albion Monitor, 6 February 2003. Available from <http://www.monitor.net/monitor/0302a/powellraqun1.html>. Internet. Accessed 9 March 2004.

Kucinich, Dennis. "House Coalition Announces Opposition To War." 19 September 2002. Available from <http://www.house.gov/apps/list/press/oh10_kucinich/ list.html>. Internet. Accessed 15 February 2004.

LTC Martins, Mark. "The CERP in Iraq," February 2004. (Draft article for publication in the Army Lawyer).

LTC Bayer, Peter. Interview by author, 8 March 2004.

LTC Gibbs, Rick. Interview by author, 8 March 2004.

Machiavelli, Niccolo, "The Prince and The Discourses. New York: Random House, 1950. 
McIntosh, Phyllis. "Protecting Iraqi Civilians: a Key Issue in Event of Military Action." 14 February 2003. Available from <http://usinfo.state.gov/regional/nea/iraq/text 2003/0214civ.htm>. Internet. Accessed 6 March 2004.

Reed, James. "Should Deterrence Fail: War Termination in Campaign Planning." Parameters (Summer 1993): 41-52. Available from <http://carlisle-www.army.mil/usawc/ Parameters/1993/reed.htm>. Internet Accessed 12 March 2004.

Rhem, Kathleen. "Iraqis Need Work, Paychecks, U.S. Administrator Says." 24 April 2003. Available from <http://www.dod.mil/news/Apr2003/n04242003_200304242.html>. Internet. Accessed 29 January 2004.

Richey, Warren. "To restore peace, US hires Iraqi looters." 9 May 2003, The Christian Science Monitor. Available from <http://www.csmonitor.com/2003/0509/p02s02-woiq.html>. Accessed 12 March 2004.

Rivkin, David Jr. and Bartram, Darin R. "Military Occupation: Legally Ensuring a Lasting Peace." Washington Quarterly 26 (Summer 2003): 87-103.

Rosen, Stephen. Wall Street Journal, 4 April 2003, sec. A p.8.

Rumsfeld, Donald H. "Testimony of United States Secretary of Defense Donald H. Rumsfeld to the Senate Armed Services Committee." 19 September 2002. Available from <http:// www.defenselink.mil/speeches/2002/s20020919-secdef2.html>. Internet. Accessed 5 March 2004.

Russell, Richard L. "War and the Iraq Dilemma: Facing Harsh Realities" Parameters (Autumn 2002): 46-61.

Sanger, David E. and Schmitt, Eric. "U.S. Has a Plan To Occupy Iraq, Officials Report." New York Times, 11 October 2002, Sec. A, p. 1.

Schmitt, Michael. "The Law of Belligerent Occupation." 15 April 2003. Available from $<\mathrm{http}$ ://www.crimesofwar.org/special//raq/news-iraq5.html>. Internet. Accessed 22 January 2004.

The Economist. "Iraq's oil -- Don't mention the O-word." 12 September 2002. Available from <http://www.economist.com/displaystory.cfm?story_id=1325264Internet>. Accessed 12 March 2004.

United States Department of State. "Powell Says U.S. Will Liberate Iraq, Give Hope To Iraqis." 25 September 2003. Available from <http://usinfo.state.gov/regional/nea/iraq/text2003/ 0331 pwl.htm>. Internet. Accessed 5 March 2004.

United Nations Security Council, Resolution 1441. S/RES/1141(2003). New York: United Nations, 8 November 2002.

United Nations Security Council, Resolution 1483. S/RES/1483(2003). New York: United Nations, 22 May 2003 
Warner, Margaret. "Days of Disorder." 11 April 2003. Available from <http://www.pbs.org/ newshour/bb/military/jan-june03/disorder_4-11.html>. Internet. Accessed 5 March 2004.

White House Office of the Press Secretary. "President Discusses the Future of Iraq." 28 April 2003. Available from <http://www.whitehouse.gov/news/releases/2003/04/iraq/200304283.html>. Internet. Accessed 20 November 2003.

White House Office of the Press Secretary. "Global Message." 2 April 2003. Available from <http://www.whitehouse.gov/ news/releases/2003/04/20030402-4.html>. Accessed 16 February 2004.

White House Office of the Press Secretary. "Operation Iraqi Freedom. Available from <http://www.whitehouse.gov/news/ releases/2003/03/20030327-10.html>. Internet. Accessed 15 February2004.

White House Office of the Press Secretary. "Operation Iraqi Freedom, Humanitarian Update." 16 April 2003. Available from <http://www.whitehouse.gov/news/releases/2003/04/ 20030416-1.html>. Accessed 6 March 2004.

White House Office of the Press Secretary. "President Bush Announces Major Combat Operations in Iraq Have Ended, Remarks by the President from the USS Abraham Lincoln At Sea Off the Coast of San Diego, California." 1 May 2003. Available from<http://www. whitehouse.gov/news/releases/2003/05/iraq/20030501-15.html>. Internet; accessed 15 February 2004.

White House Office of the Press Secretary. "President Names Envoy to Iraq." May 6, 2003. Available at <http://www.whitehouse.gov/news/releases/2003/05/20030506-5.html>. Internet. Accessed 1 March 2004.

White House Office of the Press Secretary. "Bush on Terrorism." 27 February 2002. Available from <http://www.whitehouse.gov/news/releases/2002/02/20020227-6.html>. Internet. Accessed 18 February 2004.

White House Office of the Press Secretary. "Remarks by the President Upon Return From Camp David." 23 March 2003. Available from <http://www.whitehouse.gov/news/ releases/2003/03/20030323-1.html>. Accessed 12 February 2004.

Wolfowitz, Paul. "Remarks as Prepared for Delivery by Deputy Secretary of Defense." 23 February 2003. Available at <http://www.pentagon.gov/ speeches/ 2003/ sp20030223depsecdef0042.html>. Accessed 15 February 2004.

Wong, Leonard, et al., Why They Fight: Combat Motivation in the Iraq War, U.S. Army War College, Strategic Studies Institute (July 2003). Also available from <http://carlisle-www. army.mil/ssi/pubs/2003/whyfight/whyfight.pdf>. Accessed 5 March 2004. 
